\title{
Application of project based learning in an environmental engineering programme
}

Book or Report Section

Published Version

Creative Commons: Attribution-Noncommercial-No Derivative Works 4.0

Open access

Yang, H. ORCID: https://orcid.org/0000-0001-9940-8273 (2021) Application of project based learning in an environmental engineering programme. In: Guerra, A., Chen, J., Winther, M., Kolmos, A. and Nielsen, S. R. (eds.) Educate for the future: PBL, Sustainability and Digitalisation 2021. Aalborg University Press, Aalborg, Denmark, pp. 195-205. ISBN 9788772107431 Available at http://centaur.reading.ac.uk/99206/

It is advisable to refer to the publisher's version if you intend to cite from the work. See Guidance on citing.

Publisher: Aalborg University Press

All outputs in CentAUR are protected by Intellectual Property Rights law, including copyright law. Copyright and IPR is retained by the creators or other 
copyright holders. Terms and conditions for use of this material are defined in the End User Agreement.

\section{www.reading.ac.uk/centaur}

\section{CentAUR}

Central Archive at the University of Reading

Reading's research outputs online 


\section{Aalborg Universitet}

\section{ra}

AALB ORG UNIVERSITY

DENMARK

\section{Educate for the future}

\section{PBL, Sustainability and Digitalisation 2021}

Guerra, Aida; Chen, Juebei; Winther, Maiken; Kolmos, Anette; Nielsen, Stine Randrup

Creative Commons License

CC BY-NC-ND 4.0

Publication date:

2021

\section{Document Version}

Publisher's PDF, also known as Version of record

Link to publication from Aalborg University

Citation for published version (APA):

Guerra, A., Chen, J., Winther, M., Kolmos, A., \& Nielsen, S. R. (Eds.) (2021). Educate for the future: PBL, Sustainability and Digitalisation 2021. Aalborg Universitetsforlag. International Research Symposium on PBL https://aauforlag.dk/shop/e-boeger/educate-for-the-future.aspx

\section{General rights}

Copyright and moral rights for the publications made accessible in the public portal are retained by the authors and/or other copyright owners and it is a condition of accessing publications that users recognise and abide by the legal requirements associated with these rights.

? Users may download and print one copy of any publication from the public portal for the purpose of private study or research.

? You may not further distribute the material or use it for any profit-making activity or commercial gain

? You may freely distribute the URL identifying the publication in the public portal ? 


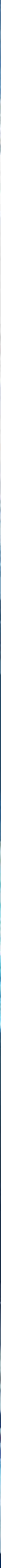

$8^{\text {th }}$ International Research Symposium on PBL

\section{EDUCATE FOR THE FUTURE: \\ PBL, SUSTAINABILITY AND \\ DIGITALISATION 2021}

Edited by:

Aida Guerra

Juebei Chen

Maiken Winther

Anette Kolmos

Stine Randrup Nielsen
त्ञाII $\pi$

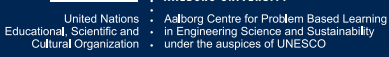

August 2021 Aalborg, Denmark 
Educate for the future: PBL, Sustainability and Digitalisation 2021

Edited by Aida Guerra, Juebei Chen, Maiken Winther, Anette Kolmos, Stine Randrup Nielsen

Series: International Research Symposium on PBL

(C) The authors, 2021

Cover designed by vestergaards.com

ISBN: 978-87-7210-743-1

ISSN: 2446-3833

Published by Aalborg University Press | forlag.aau.dk

$8^{\text {th }}$ International Research Symposium on PBL, August 15-17, 2021

Educate for the future: PBL, Sustainability and Digitalisation 2021

All the IRSPBL proceedings are available at: https://aauforlag.dk/shop/skriftserier/international-researchsymposium-on-pbl/default.aspx

The IRSPBL 2021 proceedings are officially launched during first day of the conference, August 15, 2021. The IR-SPBL 2021 conference is organised by Aalborg Centre for PBL in Engineering Science and Sustainability under the auspices of UNESCO (Denmark). The IRSPBL 2021 is a virtual event and is organised after the post-ponement of IRSPBL 2020 conference due to COVID-19 pandemic.

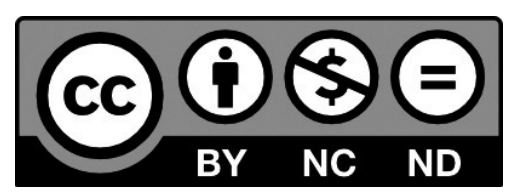

Responsibility for the content published, including any opinions expressed therein, rests exclusively with the author(s) of such content.

\section{General Copyrights}

The authors and/or other copyright owners retain copyright and moral rights for the publications made accessible in the public portal and it is a condition of accessing publications that users recognise and abide by the legal requirements associated with these rights. Users may download and print one copy of any publication from the public portal for the purpose of private study or research. You may not further distribute the material or use it for any profit-making activity or commercial gain. You may freely distribute the URL identifying the publication in the public portal.

Take down policy

If you believe that this document breaches copyright, please contact aauf@forlag.aau.dk providing details and we will remove access to the work immediately and investigate your claim.

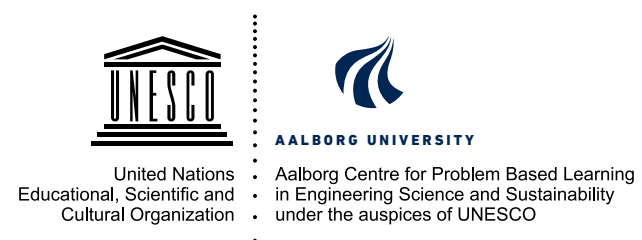




\section{Foreword}

It is a pleasure to present the proceedings from the International Research Symposium on PBL (IRSPBL2021), organised by the Aalborg UNESCO centre for PBL in Engineering Science and Sustainability. The IRSPBL has moved around the world to Australia, the United Kingdom, Malaysia, Spain, Colombia, China, and India.

Twelve years after the first symposium, it was our intention to return home and organise the IRSPBL 2020 in conjunction with the PAN-PBL annual conference, the PBL 2020. However, due to COVID 19 pandemic both conferences has been postponed for the summer of 2021, where Aalborg University is hosting an entire week dedicated to PBL, the Aalborg PBL Week 2021 (August 15-20, 2021).

Even though much has been achieved during 2020 regarding vaccination and controlling the spread of COVID-19, we are still forced in isolation and facing several waves of infection. This pandemic change the world, how we connect with each other, and carry out our academic and professional activities. We live now in a "new normal" with digitalisation, and facing social and environmental challenges. Presently, connectivity assumes new shapes and meanings; the aim of IRSPBL has been to share experiences and research results on the transformation in engineering and science education to be more project-organised, and problem-based learning, i.e., PBL.

Additionally, the amount of best practice and research has increased enormously all over the world. The need for change has also increased during these years, from requests for engineers and scientist who are able to contribute to the solution to societal challenges, such as the UN's Sustainable Development Goals and Digitalisation. Therefore, competencies such as collaboration and leadership have to be learned in inter- and disciplinary contexts as well as in complex problem solving for society, and with society.

The IRSPBL has always been proactive in bringing practitioners and researchers together, in creating communities and enabling collaborations across world. For example, with postponement of IRSPBL 2020, we organised a series of online events in the advent of IRSPBL 2021. We started with a kick-off seminar, entitled "PBL in a pandemic world", on 18 August 2020, followed by the Flipped IRSPBL 2020 webinar series, entitled "Moving towards a virtual PBL community" in the fall of 2020. The Flipped IRSPBL 2020, run from October 2020 until March 2021, took the point of departure in the IRSPBL 2020 contributions and provided the opportunity to keep the PBL community 'connected'. The Flipped IRSPBL 2020 counted with more than 200 participants from 48 different countries and all regions of the world.

Research has also proven the value of PBL and the question is no longer if PBL works, it is now a question of which type of PBL works for which learning purpose and outcome? The variation of PBL is crucial to look into, as projects for entrepreneurship and innovation might need a type of organisation of the student learning process other than projects for understanding the theoretical foundation of a discipline. There is a variation in the use and integration of digital tools for the problem-solving process and the collaborative process. There is a variation in the educational cultures and adaptiveness for co-constructed and student-centred learning processes.

The IRSPBL 2021, the postponement of IRSPBL 2020, will be fully online and free of charge. The overall goals mentioned above remain the same, and we have prepared an interactive, dynamic and comprehensive programme where, for example:

- Conversations with world-renowned experts address trending topics in engineering education;

- Networking sessions aim to foster discussion and reflection among participants, including interaction with students;

- Interactive paper presentations provides our contributors the opportunity to share their work; and

- Young researchers show case their PhD studies, among other activities.

The IRSPBL 2021 has collected 21 contributions from 13 different countries, all compiled in this book. The contributions cover a number of relevant topics: blended PBL environments and online learning; sustainability, creativity and interdisciplinarity; PBL implementation for professional competence development; assessment and management of change.

This book represents some of the newest results from research on PBL and best practice to inspire other practitioners to innovate their teaching and learning activities. We hope that you will find the book useful and inspirational for your future work.

The editors:

Aida Guerra,

Juebei Chen,

Maiken Winther,

Anette Kolmos,

Stine Randrup Nielsen 
EDUCATE FOR THE FUTURE:

PBL, SUSTAINABILITY AND DIGITALISATION 2021

Edited by Aida Guerra, Juebei Chen, Maiken Winther, Anette Kolmos and Stine Randrup Nielsen

\section{Contents}

Foreword

Blended PBL Enviroments - PBL and Online Learning

- Nicolaj Riise Clausen, Ron Ulseth and Bart Johnson Analysing Self-Directed Learning at Iron Range Engineering:

Framework and preliminary findings

- Hyunsook Oh, (John) Jong Ho Lee, Sun Kyung Yoon and Gyoo-Gun Lim

Exploring Blended IC-PBL Model \& Strategy for Course Based PBLs in University:

Using a Case Study in Engineering Education

- Kyung Jin CHA, Young Bum KIM and Gyoo Gun LIM

Application of a data-driven design-thinking approach to an industry-coupled

problem-based learning course: The case of LG Electronics-Hanyang University in Korea

Sustainability, Creativity and Interdisciplinarity in PBL

- Marco Braga, Afsaneh Hamedi d'Escoffier and Luiz d'Escoffier

Expin $^{48}$ in the Pandemic: How did Students Rebuild their Learning Network?

- Alfonso Herrera Jiménez, Fernando Bernal Martínez and Lina María Chacón Rivera

Development of the Characteristics of an Entrepreneurial University based on

the PBL Strategy: The case of Interdisciplinary ProjectsWorkshop

- Fernando José Rodriguez-Mesa, Claus Monrad Spliid and Jose Ismael Peña

60

A Case Study f or Project Work Effects i n Creativity

- Oscar Ivan Higuera-Martinez and Liliana Fernández-Samacá

Harmonizing Creative Process and P BL alignment:

an understanding of fostering creativity in Engineering Education

- Virginie Servant-Miklos

Sustainability, Identity and Learning:

Lessons from a two-year Investigation in a Problem-Based Setting

- Angie Paola Hernández Fuentes, Camilo López Mondragon, Carlos Andrés Galindo Caraballo, Daniel Andres Buitrago Torres, Dayana María Mahecha Rozo and Jhon Freddy López Medina Passion and Problem-Based Learning to Innovate and Close Inequality Gaps in the Fourth Industrial Revolution 
PBL Implementation - PBL for Professional Competence Development

- Giang Tran Thi Minh

Impact of Project Based Learning Approach on Higher Education

in Teaching Communication Skills: A Case in Vietnam

- Carola Gómez and Carola Hernández

Teachers' decision-making implications for the development of

students' autonomy in the transition to PO-PBL model

- Dan Jiang, Bettina Dahl and Pia Bøgelund

Adaptability to Problem-based Learning at Aalborg University:

Experience from four first-year Chinese engineering graduate students

- Alfonso Herrera Jiménez and Fernando Bernal Martínez

The Entrepreneurial University and the PBL

- Lucianne Leigue Aguiar, Hermano Oliveira Jr., Thais Costella, Paula Perito,

Mariana Lorenzin and Renato Pacheco Villar

Project-Based Learning and Design Thinking to Develop Skills and

Competences in High School Students

PBL Implementation, Assessment and Management of Change

- Camilla Gyldendahl Jensen, Lykke Brogaard Bertel, Thomas Ryberg and Susanne Dau

Authentic assessment as a new approach to assessing

experiential collaborative learning (ECL)

- Lina Maria Chacon Rivera, Hernán Cortés-Mora and Alfonso Herrera

Impact That The Change In The Academic Practices From Presential To Virtual Learnig

Produced On A Pbl (Problem-Based Learning) During The Covid-19 Virus Outbreak

- Ariadni Zormpa, Mourine Cheruiyot, Ann Kingiri, Rebecca Hanlin and

Margrethe Holm Andersen

Problem-based Learning: The AfricaLics Experience

- Hong Yang

Application of Project Based Learning in an Environmental Engineering Programme

- Usama Ali Ali Ebead, Khalid K. Naji, Faris Tarlochan, Abdulla Khalid A M Al-Ali and

Xiangyun Du

Development of Diverse Assessment Methods for PBL Implementation

at a Course Level in Engineering Education in Qatar 


\title{
Application of Project Based Learning in an Environmental Engineering Programme
}

\author{
Hong Yang \\ University of Reading, Reading, RG6 6AB, UK, h.yang4@reading.ac.uk
}

\begin{abstract}
Project-based learning (PBL), a learning environment in which projects drive learning, has been increasingly applied in educational programmes across various disciplines. In terms of Environmental Engineering education, the primary pedagogy still remains "chalk and talk", although many studies have confirmed its inefficacy. In the last decade, project-based learning (PBL) has been increasingly used as an effective learning method because it provides a pathway for engineering students to experience solving real-world problems as engineers. This paper researches students' learning experience and skill development in the $\mathrm{PBL}$ in one module (Air Pollution) in an Environmental Engineering programme. Students were divided into small teams working on the greenhouse gases (GHGs) $\left(\mathrm{CO}_{2}, \mathrm{CH}_{4}\right.$ and $\left.\mathrm{N}_{2} \mathrm{O}\right)$ concentrations on one university campus. With a certain level of supervision, students selected sampling sites, collected air samples, conducted laboratory measurements, calculated GHGs concentrations and presented the group presentations. A questionnaire survey was conducted to understand students' learning experience and feedback on the PBL. Semi-standardized interviews were employed to provide a micro-level view of the students' study situations, and lessons and challenges. A majority of the students applauded the PBL for its benefit of applying knowledge from lectures to field problems. In contrast to lecture-based learning, students confirmed that their interest and confidence in environmental engineering had substantially increased, together with the development of transferable skills, and understanding of teamwork and engineers' responsibilities. With the development of transnational education, further research is needed to understand the learning experience of international students, particularly those whose studies are primarily teacher-centred in their home countries.
\end{abstract}

Keywords: Project-based learning, environmental engineering, engineering education, group work, employability skills

Type of contribution: PBL best practice 


\section{Introduction}

The main pedagogy in Environmental Engineering remains "chalk and talk", although a large body of studies have confirmed its ineffectiveness. Like many disciplines, the practical classes, including field sampling and laboratory measurement, in Environmental Engineering are developed to complement material given in lectures and offer students more experience, which will be essential in their future careers as engineers. However, traditional practical classes have been criticised for their limited level of learning, as students are often unclear regarding learning objectives and incapable of applying the knowledge gained from lectures in the field. Furthermore, these practicals generally allow little space for creative thinking or contextualisation, and they are typically a testing or confirmation of the theories delivered in lectures (Mc Donnell et al., 2007).

In the last decade, project-based learning (PBL) has been progressively applied as an effective learning approach in various engineering education programmes. However, its applications in Environmental Engineering are still very limited. Similar to other disciplines, PBL may offer a path for environmental engineering students to experience addressing real-world issues as engineers and develop various employability skills (Moallem et al., 2019).

This practice study was motivated to start PBL projects regarding greenhouse gas emissions in an Environmental Engineering programme. Two research questions guided the research:

1. How is the students' learning experience during the PBL process?

2. To what extent does PBL improve students' employability skill?

\section{Literature review}

\subsection{Project-based learning}

Domin (1999) summarized the procedure, approach, and outcome of four styles of teaching: expository, inquiry, discovery and PBL (Table 1). In Environmental Engineering programmes, the most widely used one is still the expository style.

Table 1: Procedure, approach, and outcome of different laboratory instruction styles (Domin, 1999)

\begin{tabular}{cccc}
\hline Style & Procedure & Approach & Outcome \\
\hline Expository & Given & Deductive & Predetermined \\
Inquiry & Student Generated & Inductive & Undetermined \\
Discovery & Given & Inductive & Predetermined \\
PBL & Student Generated & Deductive & Predetermined \\
\hline
\end{tabular}

Unlike other learning styles, $\mathrm{PBL}$ is a learning environment in which projects drive learning. PBL is the student-centred education method in which learners work in cooperatively teams to determine what they need to study (Hmelo-Silver \& Eberbach, 2012). With a certain level of supervision, learners have ownership of the study process and they are mainly in charge of making decisions during the PBL (Guerra, 2017). As instructors, they act to facilitate the study process, instead of offering knowledge.

In addition to doing project, the 'know why' is profoundly pertaining to the problem/project design methods used in the PBL (Holgaard et al., 2017). In order to better verify the approaches taken by students, 'know why' is indispensable in the PBL. Identifying and analysing the problems is an important part of the PBL. It is important for the students to think about these problems within the context of the learning programme and also from the personal situation and interest. By this means, students don't simply 
construct or rebuild their own knowledge - it is a three-way loop study procedure, where "triple loop learning is learning that opens inquiry into underlying whys" (Isaacs, 1993).

After continuous development and improvement, the effectiveness of PBL in education has been widely reported. For example, some scholars have provided evidence on the advantages of the Aalborg University PBL model relating to learners' growth in teamwork skills, problem-solving skills, independent learning, and leadership (Clausen \& Andersson, 2019; Kolmos et al., 2009).

\subsection{Project-based learning, sustainability, and Environmental Engineering programme}

With rapid global change and a recent pandemic, engineers are not just anticipated to have scholastic knowledge and technical abilities, but also to have practical experience and various capabilities, for example, problem-solving abilities, teamwork abilities, and independent-study abilities (UNESCO, 2017). To meet the increasing requirement of the future engineers, PBL has been developed into an indispensable study approach to establish learner' different capabilities. In PBL, learners are exposed to real and complicated problems in their daily lives, and they obtain an opportunity to study and work like real engineers in the future. In this process, learners build up useful experiences and construct a bridge to close the divide between college and industry. Due to the advantage in training engineering students, the PBL approach has been increasingly applied in engineering education (Chen et al., 2021).

Environmental Engineering programmes offer training in all aspects of the supply of safe drinking water, the control of contamination, wastewater treatment, air quality control and waste management. Environmental Engineering programmes are closely related to United Nations Sustainable Development Goals (SDGs) (UN, 2021). SDGs aim to deal with the world's most difficult challenges, such as global warming, biodiversity loss, and air and water pollution. Education plays an important role in teaching the public to be aware of the various SDG crises. Higher education, such as engineering programmes, has an important role to play in training future workforces to mitigate or tackle these sustainability crises (Desha, 2013). For a better sustainability education, researchers have found that pedagogies that promote cooperative problem-solving are essential (Segalas et al., 2010). In engineering education, Coral (2009) and Guerra (2014) have suggested problem-based group projects teaching is one of the most effective approaches to enhance the awareness and behaviour of sustainability. In addition, several researchers have suggested the importance of system-thinking (Dowling et al., 2020) and trans-disciplinarity education (Byrne \& Mullally, 2016) in engineering education for sustainability, due to the complexity of the sustainability challenge as laid out by the SDGs and increasing complexity of new technologies, such as Al and 5 G.

Despite the extensive application of PBL in engineering education, the application of PBL in Environmental Engineering still remains in infancy. Requires et al. (2018) applied PBL in the Environmental Engineering programme at the University of the Basque Country, Spain, and they found PBL was a very motivating approach for the curricular development and attaining students' study outcomes. Studying in small groups, learners' independent-learning skills have also been developed. However, it is still not clearly understood for students' learning experience and employability skills development in PBL process in the Environmental Engineering programmes.

Taking the above into consideration, this study applied the PBL to an Environmental Engineering programme at a British university. Studying in small groups, students conducted projects to explore greenhouse gas emissions from the university campus. The questionnaire survey and interviews were conducted to understand students' learning experience and employability capability development. 


\section{Methodology}

\subsection{Project implementation}

The PBL projects were implemented by a group of 34 Year 3 Environmental Engineering students studying for the Air Pollution module. Figure 1 shows the implementation of the projects. Because of the increasing global attention on climate change, students proposed projects on greenhouse gas emission from the university campus. Supervisors provided the necessary theories in lectures and made them readily obtainable. In addition, supervisors provided an outline of the problems, which are related to the project objectives. Students worked in small teams, searched and read relevant references, completed a literature review, and developed a detailed group project plan. Referring to published work, students identified field work and laboratory measurements and conducted a risk assessment of both field and laboratory work. Students carried out some pilot field and laboratory work, and supervisors provided some feedback on the preliminary results. If necessary, the original project plan might be revised before the formal start of the project. Working in groups, students conducted field sampling and laboratory measurements. Based on the group findings, each group presented a group presentation, and all students also submitted an individual report.

Specifically, the main aim of the projects is to understand the greenhouse gas (GHGs) emissions from one university campus. Students analysed the university campus map and identified five sites with possible various levels of GHGs: 1 . a classroom, 2. the university library, 3. a student hall, 4, sport ground, and 5. near a lake (Figure 2). There are different kinds of GHGs. With guidance from supervisors, students focused on three important gases: carbon dioxide $\left(\mathrm{CO}_{2}\right)$, methane $\left(\mathrm{CH}_{4}\right)$, and nitrous oxide $\left(\mathrm{N}_{2} \mathrm{O}\right)$. Air samples were collected using a plastic syringe with a two-way stopcock. At each site, three samples were collected. $\mathrm{CO}_{2}$, $\mathrm{CH}_{4}$ and $\mathrm{N}_{2} \mathrm{O}$ were analysed in the laboratory using an Agilent 7890 B Gas Chromatography with Flame Ionisation Detector (FID) and Electronic Capture Detector (ECD) (Yang et al., 2015).

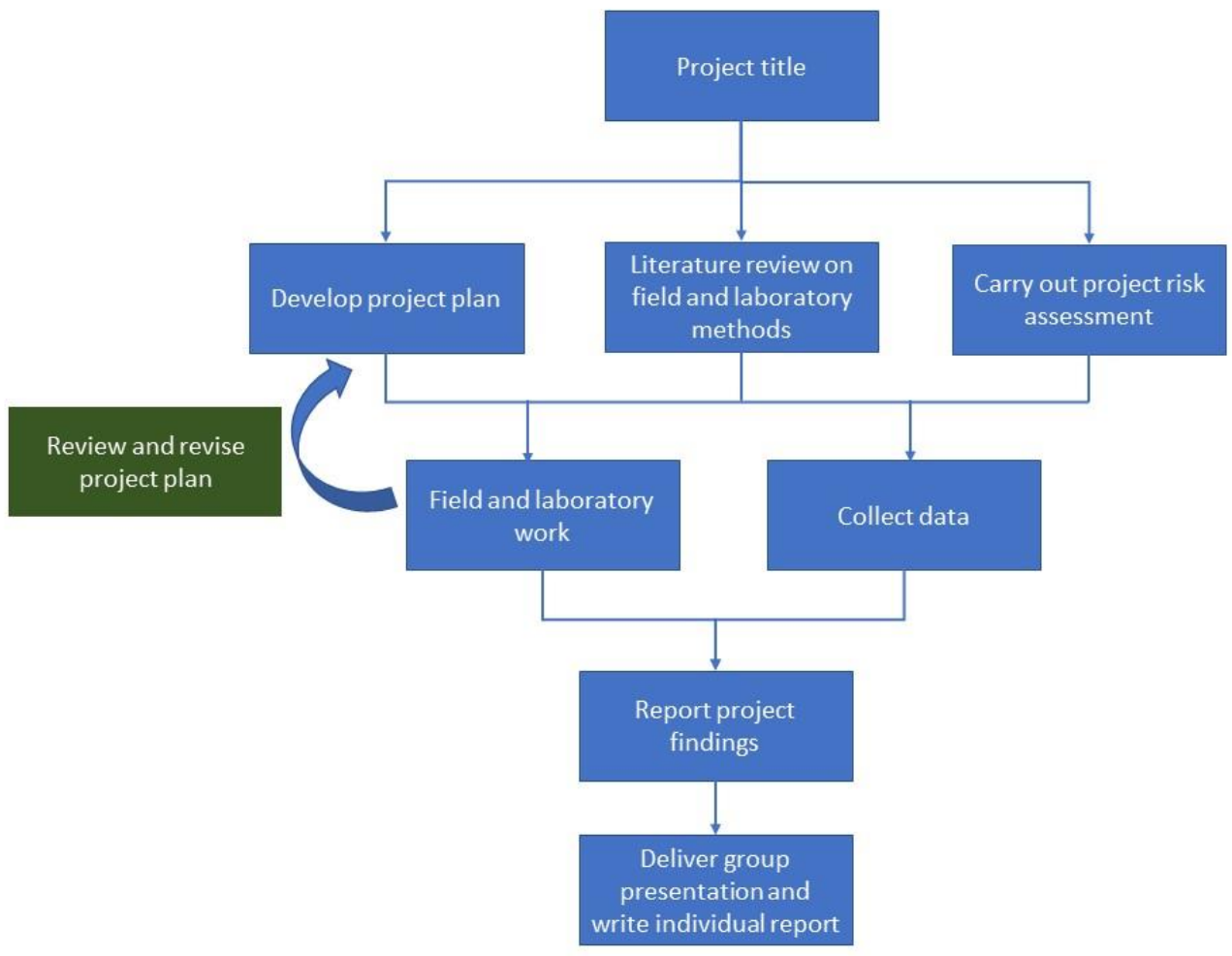

Figure 1: Implementation of project based learning (PBL) in an Environmental Engineering Programme

(After Mc Donnell et al., 2007) 

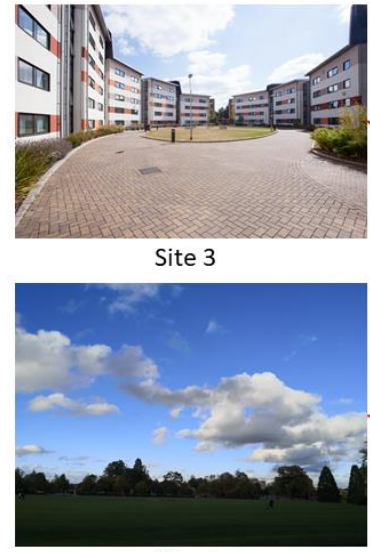

Site 4

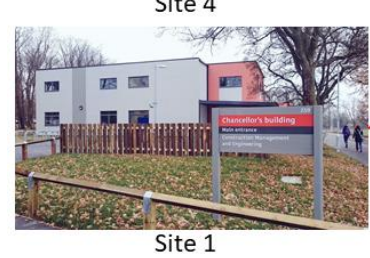

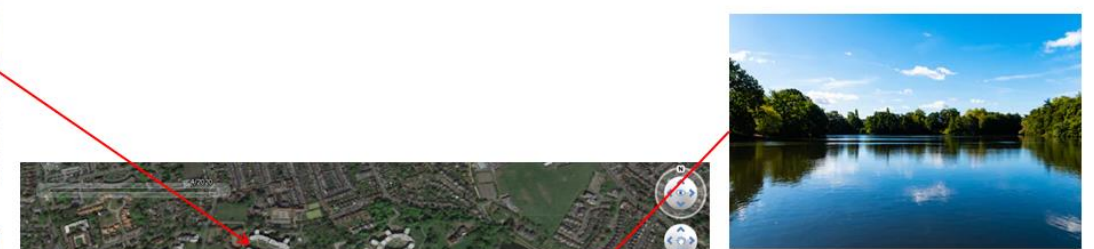

Site 5

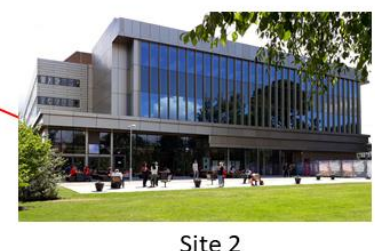

Site 2

Figure 2: Sites for collecting air samples on one university campus. (1) Classroom, (2) Library, (3) Student hall, (4) Sport ground, and (5) Near a lake. The map is from Google Earth.

On completion of projects, each team was required to give a 15-minute group presentation, a graded coursework weighting of $20 \%$. The key criteria searched for were capability in analysing data, presenting their team findings, together with the ability to respond to questions. In addition, each student will submit an individual report, with an assessment weight of $80 \%$. The supervisors looked for the evidence that students had conducted some research on the topic, correctly analysed the data, and clearly written the report.

\subsection{Survey of students' learning experience and skill development in the PBL}

To understand students' learning experience and skill development in the PBL process, a questionnaire survey was conducted. Semi-standardized interviews were also employed to provide a micro-level view of the students' learning experience and skill development during the PBL process. A total of seven students were interviewed to explore their learning experience during the PBL period. To analyse the interview data, this study applied a qualitative thematic analysis method, characterised by small sample size, abundant data analysis and a focus on transferability instead of generalizability (Braun \& Clarke, 2012).

\section{Results}

\subsection{Greenhouse gas emissions from one university campus}

Students worked in groups and collected air samples from five sites on the university campus using plastic syringes with two-way stopcocks (Figure 3) and measured the GHGs concentrations in the laboratory. The results indicated higher GHGs concentrations on the campus than the global averages (Table 2). There is large variation in $\mathrm{CO}_{2}$, while much smaller variations in $\mathrm{CH}_{4}$ and $\mathrm{N}_{2} \mathrm{O}$ on the campus. The coefficients of variation in $\mathrm{CO}_{2}, \mathrm{CH}_{4}$ and $\mathrm{N}_{2} \mathrm{O}$ between the five sites were $39.31 \%, 10.12 \%$ and $9.38 \%$, respectively (Table 2). Specially, the indoor environment (classroom, library, and student hall) had much higher $\mathrm{CO}_{2}$ concentration, with a mean of 703.63 ppm, than outdoor environment (sport ground and lake), with an average of 427.60 ppm. 
(A)

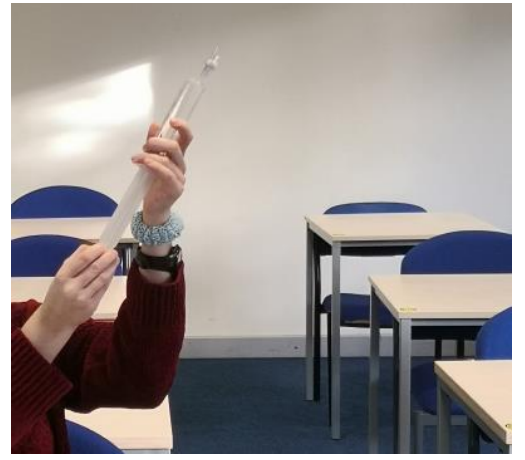

(B)

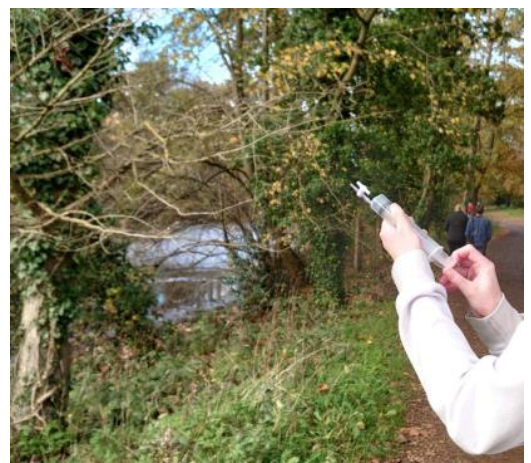

Figure 3. Students collected air samples in a classroom (A) and near a lake (B) using plastic syringes with two-way stopcocks.

Table 2. Concentrations of greenhouse gases (ppm) on one university campus.

\begin{tabular}{lrll}
\hline \multicolumn{1}{c}{ Sites } & \multicolumn{1}{c}{$\mathrm{CO}_{2}$} & $\mathrm{CH}_{4}$ & $\mathrm{~N}_{2} \mathrm{O}$ \\
\hline Classroom & 557.84 & 2.387 & 0.416 \\
Library & 531.45 & 2.359 & 0.430 \\
Student hall & 1021.61 & 2.454 & 0.458 \\
Sport ground & 368.01 & 2.321 & 0.420 \\
Whiteknights Lake & 443.91 & 2.660 & 0.420 \\
Global average & 411.29 & 1.872 & 0.332 \\
\hline
\end{tabular}

\subsection{Questionnaire Results}

According to the questionnaire survey results, more than $90 \%$ students agreed that the PBL inspired them to learn more about the module (Figure 4). $98 \%$ of students definitely agreed that this module was designed in a way to help them learn. $96 \%$ of students definitely agreed that the teaching method, PBL, helped to create a sense of belonging within the module cohort. $98 \%$ of students definitely agreed that there were adequate opportunities to interact with other students on the module. Students' competencies have been developed significantly during the PBL process. In particular, $92 \%$ of the students definitely agreed that this module enabled them to develop their abilities as independent learners.

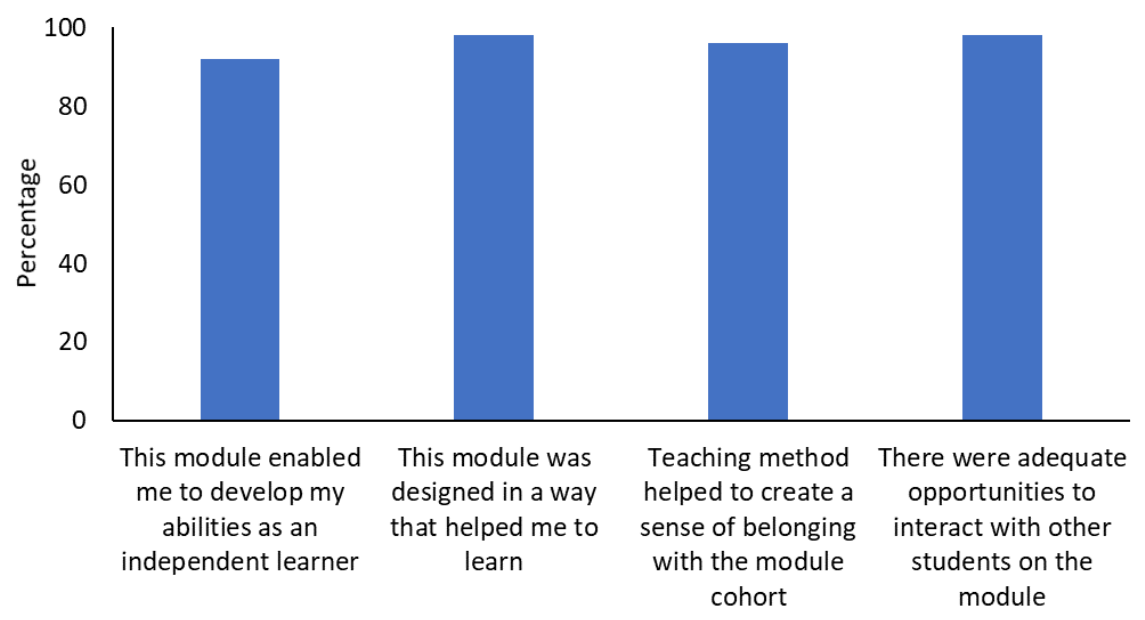

Figure 4. Percentages of students definitely agree with the evaluations of the module. 


\subsection{Interview Results}

In order to make interview results more visible, the words that are most used throughout the interviews were counted and the most repeated words were applied to create a word cloud (Figure 5). Project, group, students, and together were mentioned very frequently by the interviewees.

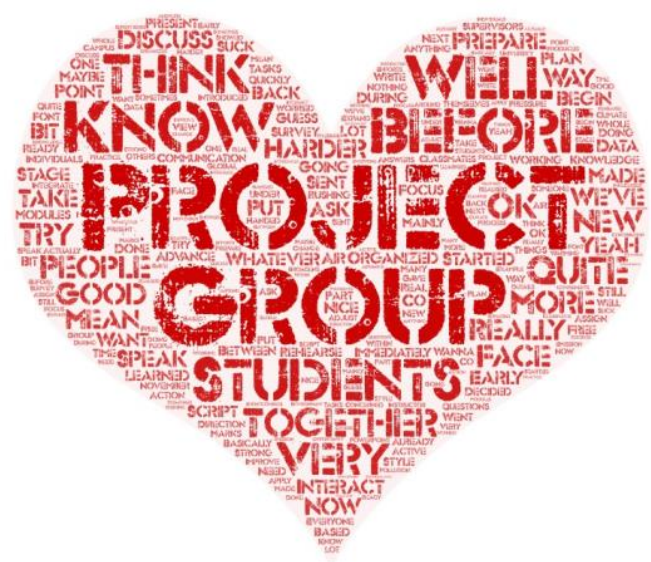

Figure 5. A word cloud extracted from interview transcripts.

\subsubsection{Students enjoyed PBL}

Similar to the questionnaire results, PBL has received positive feedback from interviewees. Students enjoyed the PBL and started the projects very quickly, as exemplified by one student:

I think the students in our group have been very active in the project. After the instructor introduced the project-based learning, we immediately discussed it. Well, that's very great.

Unlike the traditional teaching of "chalk and talk", the PBL gave students the opportunity to get to know each other and work on the same project. This was echoed by many students, as exemplified by the following comment:

It is harder to interact with classmates in other modules, but the group projects mean you can speak with new people you don't know before.

\subsubsection{PBL linked knowledge with practice}

In the PBL, the fundamental change of students' learning is the chance to connect theories to practice. Traditionally, theoretical knowledge was generally obtained from lectures. When learners carried out PBL, they were immersed in these real-world problems and learned and worked in small teams. This real-life link is a means to perform professional training, i.e. engineering training. In addition, learners were trained to be independent learners and more responsible for their projects. More importantly, once again, the PBL gave students an opportunity to apply the knowledge they learned to various projects. For instance, one student stated:

I know about the knowledge of climate change and global warming, but I have not yet noticed the $\mathrm{CO}_{2}$ emissions from our university campus. These projects gave me an opportunity to apply what I learned in practice, in the real environment around me. 


\subsubsection{PBL developed multiple skills}

Working on the same project, students need to communicate with other team members, collaborate with others, develop their sampling methods and laboratory measurement skills, and conduct all work within a limited period. Different from the traditional learning approaches, students have more opportunities to establish their abilities through the PBL process. Students addressed their growth of teamwork skills, communication skills, problem-solving skills, and time management skills. With the development of teamwork skills, students were proud of the achievement of group work, as exemplified by one student:

Because we all contributed to the process, it showed the efforts we made together.

During the teamwork, students learned from their team members. For example, one student began to think about air pollution from different angles:

Group projects can expand your thinking in many ways. For example, I might think about how air pollution is produced, but other students either think about the details from another point of view. ......For me, it broadens my knowledge. .......t complements my shortcomings.

\section{Discussion}

The student-led projects were successfully conducted on one university campus. The results indicate higher greenhouse gas emissions from the university campus. In addition, $\mathrm{CO}_{2}$ indoors is higher than outdoors, and the similar phenomena has been observed in other places (Lee \& Chang, 2000).

Same to many studies (Kolmos et al., 2019; Prosser \& Sze, 2014; Schwartz et al., 2001), this research shows students welcome the PBL and their comments on PBL are generally positive. In terms of the students' PBL learning experience, most students liked the new form of learning. Due to the strong interest in the projects which were originally proposed by students in small groups, students were very active and started the projects without any further waiting. This has been confirmed by many interviewees. Through the PBL, students in this Environmental Engineering programme knew more about their classmates, and even knew some new classmates whom they had never met before. Employability skills have been essential for all engineering education programmes. In this study, almost all interviewees have praised the PBL for its importance in enhancing their team-work and communication skills. With the rapid development of new knowledge and technology, engineering graduates should be lifelong learners. Therefore, it is essential to train the engineering students to be independent learners during their time at the university. As shown in Figure 1, more than $90 \%$ of students applauded PBL for the significance of improving their independent learning skill. Similarly, a study at Taylor's University suggested that the majority of students have improved their employability skills, for example, team-working, analysing data, problem-solving, report writing, presentation and time management, through PBL (Hsiung, 2019). Students also stated "It (PBL) was nice working more closely with people from my class" (Mc Donnell et al., 2007). With a certain level of supervision from instructors, students "learned to do more by themselves" (Mc Donnell et al., 2007). In PBL, the opportunity to use various equipment to measure air quality excited students' interests and made the study process more engaging. Learning by carrying out projects also sustains learners' deep learning, and improved learning outcomes were widely reported (Kolmos et al., 2009; Schwartz et al., 2001).

To explore engineering identity, Godwin (2016) proposed a theoretical framework that included three dimensions: performance, recognition and interests. The engineering identity was advanced via collaboration with team members within the practice community. Due to the PBL's advantages in linking theories with practice, PBL can reduce the gap between universities and industries, enhancing learners' study performance and future job performance. In the interviews, students have emphasized the importance of linking knowledge with practice in PBL. In the teamwork on GHGs emissions from the university campus, students have recognized the strengths of other team members and learned to collaborate with each other. In the meantime, many students had become more interested in the Air Pollution module and chose to do the related topics for their dissertations. 
With the rapid development of transnational education, an increasing number of international students are studying in European universities (Yang, 2020). Some international students have not conducted any PBL in their home universities. Scholars have found that cultural differences can cause some challenges for international students' PBL experience (Du \& Hansen, 2005). A recent survey of six international students found that the PBL is an effective way to develop their teamwork skills, communication skills, problemsolving skills, emotion and time management skills, while these students have some difficulties in the beginning of the PBL and more support is required (Chen et al., 2020).

Similar to many studies, there are some limitations in the current research. There are seven students in the current interviews. In future studies, a larger sample size will further enhance our understanding of the effect of PBL on Environmental Engineering students' learning. As Chen et al. (2020) have pointed out the study challenges of international students in the PBL process, more researches are needed to understand the learning experience of overseas students, particularly those whose studies in home countries are heavily in teacher-centred mode.

\section{Conclusion}

This practice paper presents an initiative to apply the PBL in the projects of greenhouse gas emission from one university campus in an Environmental Engineering programme. The questionnaire and interview survey results provide evidence to confirm that PBL can effectively relate the knowledge from lecture to practice, including field sampling, laboratory measurement, analysing data, writing reports, and orally presenting results. Because the projects were proposed by students working in small groups, most students showed strong interest in actively conducting the projects with team members. While the majority of the students enjoyed the PBL, students have emphasized the improved employability skills including team-work, communication, data analysis, and presentation. Especially, more than $90 \%$ emphasized their enhanced independent learning skills during the PBL. Further research could include challenges for international students in the PBL and extra help or training for these students.

\section{Acknowledgement}

This work is partially supported by Teaching and Learning Enhancement Projects (TLEP) and School Research Fund, University of Reading, UK.

\section{References}

Braun, V., \& Clarke, V. 2012. Thematic analysis. In: H. Cooper, P. Camic, M, D. Long, L, A. Panter, T, D. Rindskopf, \& K. Sher, J. (Eds.), APA Handbook of Research Methods in Psychology, Vol 2: Research Designs: Quantitative, Qualitative, Neuropsychological, and Biological (Vol. 10, pp. 57-71). American Psychological Association.

Byrne, E. P., \& Mullally, G. 2016. Seeing beyond silos: Transdisciplinary approaches to education as a means of addressing sustainability issues. In: W. Leal Filho \& S. Nesbit (Eds.), New Developments in Engineering Education for Sustainable Development (pp. 23-34). Springer.

Chen, J., Kolmos, A., \& Du, X. 2020). The Role of Teamwork on Students' Engineering Professional Identity Development in the AAU PBL Model: From the Perspectives of International Engineering Students. In: Educate for the future: PBL, Sustainability and Digitalisation 2020, Aalborg Universitetsforlag International Research Symposium on PBL, Aalborg, Danmark.

Chen, J., Kolmos, A., \& Du, X. 2021. Forms of implementation and challenges of PBL in engineering education: a review of literature. European Journal of Engineering Education, 46, 90-115. 
Clausen, H. B., \& Andersson, V. 2019. Problem-based learning, education and employability: a case study with master's students from Aalborg University, Denmark. Journal of Teaching in Travel \& Tourism, 19, 126139.

Desha, C. X. 2013. Higher education and sustainable development: A model for curriculum renewal. Routledge.

Domin, D. S. 1999. A review of laboratory instruction styles. Journal of Chemical Education, 76, 543-547.

Dowling, D., Hadgraft, R., Carew, A., McCarthy, T., Hargreaves, D., Baillie, C., \& Male, S. 2020. Engineering your future: an Australasian guide. John Wiley \& Sons.

Du, X., \& Hansen, S. 2005. Confronting cultural differences: learning engineering as foreigners in a Danish context: a case study of Chinese students. A Journal for Science and Technology Studies, 17, 61-84.

Godwin, A. 2016). The development of a measure of engineering identity. In: The $123^{\text {rd }}$ Annual Meeting for the American Society for Engineering Edcuation, Jun 26-29, New Orieans, LA.

Guerra, A. (2014). Problem Based Learning and Sustainable Engineering Education: Challenges for $21^{\text {st }}$ Century. PhD, Aalborg University: Aalborg, Danmark.

Guerra, A. 2017. Integration of sustainability in engineering education Why is PBL an answer? International Journal of Sustainability in Higher Education, 18, 436-454.

Hmelo-Silver, C. E., \& Eberbach, C. 2012. Learning theories and problem-based learning. In: S. Bridges, C. McGrath, \& T. Whitehill (Eds.), Problem-based learning in clinical education (pp. 3-17). Springer.

Holgaard, J. E., Guerra, A., Kolmos, A., \& Petersen, L. S. 2017. Getting a Hold on the Problem in a ProblemBased Learning Environment. International Journal of Engineering Education, 33, 1070-1085.

Hsiung, W. Y. 2019. Embedding employability skills into first year undergraduate students to enhance graduate capabilities. International Journal of Education, 4, 71-82.

Isaacs, W. N. 1993. Taking Flight - Dialog, Collective Thinking, and Organizational Learning. Organizational Dynamics, 22, 24-39.

Kolmos, A., Bøgelund, P., \& Spliid, C. M. 2019. Learning and Assessing Problem - Based Learning at Aalborg University: A Case Study. In: M. Moallem, W. Hung, \& N. Dabbagh (Eds.), The Wiley Handbook of Problem Based Learning (pp. 437-458). Wiley Blackwell.

Kolmos, A., De Graaff, E., \& Du, X. 2009. Diversity of PBL-PBL learning principles and models. In: X. Du, E. de Graaff, \& A. Kolmos (Eds.), Research on PBL practice in engineering education (pp. 9-21). Sense Publishers.

Lee, S. C., \& Chang, M. 2000. Indoor and outdoor air quality investigation at schools in Hong Kong. Chemosphere, 41, 109-113. 
Mc Donnell, C., O'Connor, C., \& Seery, M. K. 2007. Developing practical chemistry skills by means of student-driven problem based learning mini-projects. Chemistry Education Research and Practice, 8, 130139.

Moallem, M., Hung, W., \& Dabbagh, N. 2019. The Wiley Handbook of Problem - Based Learning. Wiley Blackwell.

Prosser, M., \& Sze, D. 2014. Problem-based learning: Student learning experiences and outcomes. Clinical Linguistics \& Phonetics, 28, 131-142.

Requies, J. M., Agirre, I., Barrio, V. L., \& Graells, M. 2018. Evolution of Project-Based Learning in Small Groups in Environmental Engineering Courses. Journal of Technology and Science Education, 8, 45-62.

Schwartz, P., Mennin, S., \& Webb, G. 2001. Problem-based learning: Case studies, experience and practice. Kogan Page.

Segalàs Coral, J. 2009. Engineering education for a sustainable future. Universitat Politècnica de Catalunya.

Segalas, J., Ferrer-Balas, D., \& Mulder, K. F. 2010. What do engineering students learn in sustainability courses? The effect of the pedagogical approach. Journal of Cleaner Production, 18, 275-284.

UN. 2021. Sustainable Development Goal. https://sdgs.un.org/goals.

UNESCO. 2017. Education for Sustainable Development Goals Learning Objectives. https://unesdoc.unesco.org/ark:/48223/pf0000247444.

Yang, H. (2020). Evaluating the study experience for Chinese students at a UK university. PostGraduate Certificate in Academic Practice (PGCAP), University of Reading: Reading, UK.

Yang, H., Andersen, T., Dörsch, P., Tominaga, K., Thrane, J.-E., \& Hessen, D. O. 2015. Greenhouse gas metabolism in Nordic boreal lakes. Biogeochemistry, 126, 211-225. 


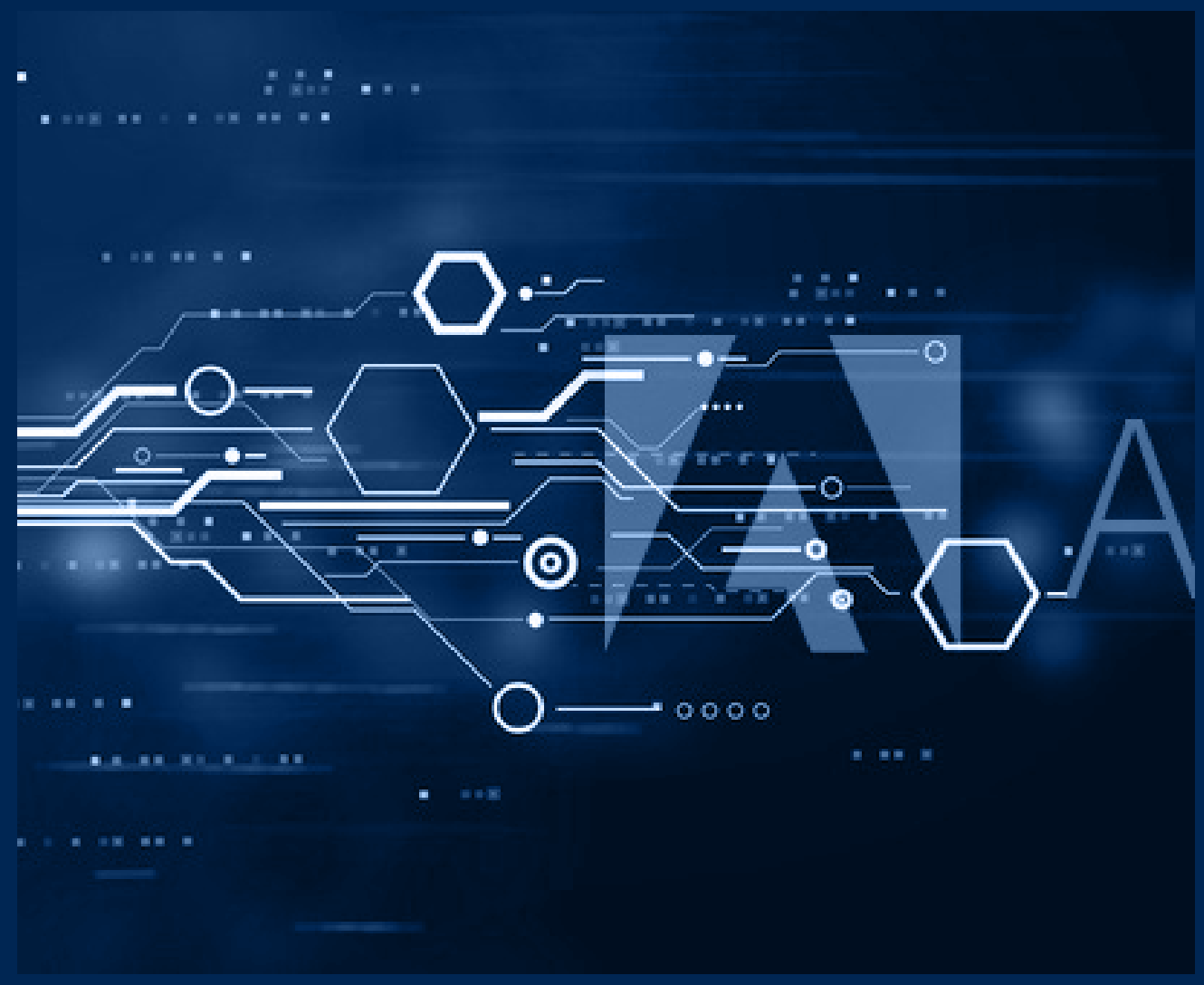

In this book we present the contributions from the International Research Symposium on PBL (IRSPBL2021), organised by the Aalborg UNESCO centre for PBL in Engineering Science and Sustainability.

The IRSPBL 2021 has collected 21 contributions from 13 different countries, all compiled in this book. The contributions cover a number of relevant topics: blended PBL environments and online learning; sustainability, creativity and interdisciplinarity; PBL implementation for professional competence development; assessment and management of change.

This book represents some of the newest results from research on PBL and best practice to inspire other practitioners to innovate their teaching and learning activities. We hope that you will find the book useful and inspirational for your future work. 